\title{
Lactation curves and model evaluation for feed intake and energy balance in dairy cows
}

\author{
I. Harder ${ }^{1 *}$ E. Stamer, ${ }^{2}$ W. Junge, ${ }^{1}$ and G. Thaller ${ }^{1}$ \\ ${ }^{1}$ Institute of Animal Breeding and Husbandry, Christian-Albrechts-University, D-24098 Kiel, Germany \\ ${ }^{2}$ TiDa Tier und Daten GmbH, D-24259 Westensee/Brux, Germany
}

\section{ABSTRACT}

A good health status of high-performing dairy cows is essential for successful production. Feed intake affects the metabolic stability of dairy cows and can be used as a measurement for energy balance. By implementing feed intake and energy balance into the breeding goal, these traits provide great potential for an improvement in the health of dairy cows by breeders. In this study, fixed and random regression models were tested to establish appropriate models for a further analysis of this approach. A total of 1,374 Holstein-Friesian cows and 327 Simmental cows (SI) from 12 German research farms participating in a collaboration called optiKuh were phenotyped. Feed intake data recording was standardized across farms, and energy balance was calculated using phenotypic information on milk yield, milk ingredients, live weight, gestation stage, and feed intake. The phenotypic data set consisted of a total of 40,012 Holstein-Friesian and 16,996 SI with average weekly dry matter intakes of $21.8 \pm 4.3$ and $20.2 \pm 3.6$ $\mathrm{kg} / \mathrm{d}$, respectively. Observations of days in milk 1 to 350 were used to evaluate the best-fitting models and to estimate the repeatability and correlations between cow effects at different stages for feed intake and energy balance. Four parametric functions (Ali and Schaeffer and Legendre polynomials of second, third, and fourth degree) were compared to model the lactation curves. Based on the corrected Akaike information criterion and the Bayesian information criterion, the goodness of fit was evaluated to choose the best-fitting model for the finest description of lactation curves for the traits energy balance and feed intake. Legendre polynomial fourth degree was the best-fitting model for random regression models. In contrast, Ali and Schaeffer was the best choice for fixed regression models. Feed intake and energy balance acted as expected: the feed intake increased slowly at the beginning of lactation and the

Received June 28, 2018.

Accepted April 10, 2019.

*Corresponding author: iharder@tierzucht.uni-kiel.de negative energy balance switched to a positive range around 40 to $80 \mathrm{~d}$ of lactation. The repeatabilities of both traits were quite similar and the repeatabilities for SI were the highest for both traits. Additionally, correlations between cow effects were closest between early days in milk. These results emphasize the possibility that the unique optiKuh data set can be used for further genetic analyses to enable genomic selection for feed intake or energy balance.

Key words: optiKuh, feed intake, energy balance, random regression

\section{INTRODUCTION}

Feed intake (FI) is a very important trait for highperformance dairy cows for various reasons. On the one hand, feed costs represent up to $50 \%$ of dairy production costs and consequently have a major effect on the economic success of livestock farming (Connor, 2015). On the other hand, FI strongly influences the health maintenance of dairy cows and therefore is an important factor for animal welfare in dairy production (Boichard and Brochard, 2012). Milk yield (MY) is highly correlated with FI. However, FI cannot compensate for the increased energy requirements especially in early lactation stages (Ingvartsen and Andersen, 2000). Since an increase in FI is slower than an increase in milk production, body reserves that were generated during gestation are used to compensate for the resulting energy deficit (Coffey et al., 2002). This is a normal reproduction strategy of mammals. However, since dairy breeding strategies focused for a long time only on increasing milk production, they slip into a severe and lengthy intensified postpartum energy deficit that can be associated with metabolic diseases (de Haas et al., 2015). Cows with an extreme state of negative energy balance (EB) are more susceptible to metabolic diseases such as acidosis, ketosis, and milk fever (Collard et al., 2000; Spurlock et al., 2012; von Leesen et al., 2014) and a decline in fertility (Butler, 2003). This indicates that the deficit depends not only on the amount of milk produced, but also on FI (Buttchereit et al., 2010). 
So, high FI at the beginning of lactation could counteract these problems, and therefore, FI should be part of the dairy cow breeding goal. This is in contrast to the generally valid goal of an efficient cow, which should eat less but produce more (Veerkamp et al., 2013). However, the improvement in feed efficiency causes a worsening in EB along with a rise in cows' health problems. Therefore, it makes sense to breed on a high FI at the beginning of lactation to overcome the difficult period although it causes problems with efficiency.

Therefore, reliable FI phenotypes have to be recorded, which presents practical challenges for dairy farms. The measurement of FI is complicated, expensive, and connected to a high number of technical requirements (Coffey et al., 2004; Berry et al., 2007; de Haas et al., 2012). In previous studies, data sets have consisted of data collected on several experimental farms, which have resulted in an insufficient database (Veerkamp et al., 2013; Berry et al., 2014). To improve FI or $\mathrm{EB}$, respectively, genomic selection provides the most practical approach, because this eliminates the need to collect phenotypes for each animal and achieves higher accuracies compared with traditional selection (Connor, 2015; Yao et al., 2017).

In the optiKuh project, a collaboration of 12 German research farms was established. All of the research farms provided the technical equipment for consistent measurement of unique FI phenotypes. In this way a unique data set was created, providing the possibility to consider the traits FI and EB in the breeding goal to support the health and fertility of dairy cows (Veerkamp et al., 2000; Coffey et al., 2001, 2002).

A little success could be generated in developing breeding values for FI to select for this trait (Berry et al., 2014).

The traits FI and EB can be measured at different intervals (e.g., test day, test week, and so on), which can be evaluated using different models. These include repeatability models, multi-trait models, and random regression models with different functions (Buttchereit et al., 2010; Spurlock et al., 2012; Li et al., 2018; Uddin et al., 2018).

In the evaluation of the genetic merit of dairy cows, test-day models are used for repeated records of production traits (Berry et al., 2014). One type of these models is the random regression model, which is the model of choice to use the given benefits to account for individual differences in the shape of lactation and environmental factors that affect cows at different stages of lactation (Jamrozik and Schaeffer, 1997; Jensen, 2001; Banos et al., 2012). However, a fixed average lactation curve and a random regression for the individual deviations are used to model a lactation curve of a cow in the random regression model (Pool et al., 2000).
The objective of this study was to pool FI and EB data of 12 German dairy research farms. A subsequent joint analysis of these traits was to establish a basis to consider FI in the breeding goal of high-performance dairy cows to support health and fertility, especially at the beginning of lactation. Therefore, the aim was to develop well-suited statistical models for both variance component estimation and breeding value estimation of the traits FI and EB.

\section{MATERIALS AND METHODS}

The phenotype data for FI and EB originated from 1,374 Holstein-Friesian (HF) and 327 Simmental (SI) cows. Individual FI was recorded from December 2014 to March 2017 on 12 German research farms (Achselschwang, Aulendorf, Braunschweig, Dummerstorf, Grub, Futterkamp, Hohenheim, Iden, Karkendamm, Neumühle, Riswick, and Triesdorf). The individual FI of each dairy cow was measured via feeding troughs equipped with a weighing unit and automatic cow identification. The farms involved in the project optiKuh were divided into $\mathrm{A}$ and $\mathrm{B}$ farms. In $\mathrm{A}$ farms, projectspecific feeding trials were performed with different roughage energy levels (6.5 vs. $6.1 \mathrm{MJ}$ of $\mathrm{NE}_{\mathrm{L}} / \mathrm{kg}$ of $\mathrm{DM}$ ) and different amounts of concentrates (250 vs. $150 \mathrm{~g} / \mathrm{kg}$ of ECM). The $\mathrm{NE}_{\mathrm{L}}$ represents net energy of lactation defined as the amount of energy in a feed that is available for milk production and body maintenance (Kirchgeßner, 2014). The ECM contains $4 \%$ fat and $3.4 \%$ protein (according to Kirchgeßner, 2014).

$$
\begin{gathered}
\operatorname{ECM}(\mathrm{kg} / \mathrm{d})=\mathrm{MY}(\mathrm{kg} / \mathrm{d}) \times\{[1.05+0.38 \\
\times \text { milk fat }(\%)+0.21 \times \text { milk protein }(\%)] / 3.28\} .
\end{gathered}
$$

In B farms, cows were fed with partly mixed, farmspecific rations (PMR) or TMR. The only restriction on B farms for farm-specific, high-yield cow rations was a target value for concentrations of $250 \mathrm{~g} / \mathrm{kg}$ of ECM. The realized feeding groups together with the duration of the trials are displayed in Table 1. All cows were fed ad libitum. If the compilation of the components changed, the rations were calculated again. If more than one analysis per component within ration was carried out, the mean was taken. The frequency of sampling differed between research farms. Every farm computed and allocated information for each day and ration (and types of concentrate).

Data were edited and summarized within farm. Due to the different frequencies of measurement (e.g., daily FI and weekly milk ingredients) the data were computed within each calendar week as mean values. Most of the research farms collected FI data during the dry 
Table 1. Research farms with diets, feeding groups, and duration of trials

\begin{tabular}{|c|c|c|c|c|c|c|c|c|}
\hline Group & Research farm & Breed $^{1}$ & Diet & \multicolumn{4}{|c|}{ Feeding group ${ }^{2}$} & $\begin{array}{l}\text { Duration } \\
(\mathrm{mo})\end{array}$ \\
\hline $\mathrm{A}$ & Braunschweig & $\mathrm{HF}$ & TMR & & $\mathrm{X}$ & & $\mathrm{X}$ & 8 \\
\hline A & Riswick (A) & $\mathrm{HF}$ & PMR & $\mathrm{X}$ & $\mathrm{X}$ & $\mathrm{X}$ & $\mathrm{X}$ & 24 \\
\hline A & Aulendorf & SI & TMR & & & $\mathrm{X}$ & $\mathrm{X}$ & 24 \\
\hline A & Grub & SI & PMR & $\mathrm{X}$ & $\mathrm{X}$ & $\mathrm{X}$ & $\mathrm{X}$ & 24 \\
\hline $\mathrm{A}$ & & & & \multicolumn{4}{|c|}{ Number of feeding groups - trial variants ${ }^{4}$} & \\
\hline B & Futterkamp I & $\mathrm{HF}$ & TMR & \multicolumn{4}{|c|}{2 - different amounts of essential oils } & 3 \\
\hline $\mathrm{B}$ & Futterkamp II & $\mathrm{HF}$ & TMR & \multicolumn{4}{|c|}{2 - different amounts of carbohydrates } & 3 \\
\hline B & Futterkamp III & $\mathrm{HF}$ & TMR & \multicolumn{4}{|c|}{2 - mycotoxin binder } & 3 \\
\hline B & Iden 2015 & $\mathrm{HF}$ & TMR & & 6 \\
\hline B & Iden 2016 & $\mathrm{HF}$ & TMR & & & & $\begin{array}{l}2 \text { - different amounts of carbohydrates } \\
1\end{array}$ & 6 \\
\hline B & Hohenheim & $\mathrm{HF}$ & TMR & \multicolumn{4}{|l|}{1} & 18 \\
\hline B & Achselschwang & SI & PMR & \multicolumn{4}{|c|}{2 - different concentrate levels } & 3 \\
\hline $\mathrm{B}$ & Achselschwang & SI & PMR & \multicolumn{4}{|c|}{$\begin{array}{l}4 \text { - different amounts of grass and corn } \\
\text { silage and } 2 \text { concentrate levels }\end{array}$} & 4 \\
\hline B & Achselschwang & SI & PMR & \multicolumn{4}{|c|}{2 - different chop lengths of corn silage } & 2 \\
\hline
\end{tabular}

${ }^{1} \mathrm{HF}=$ Holstein-Friesian; SI = Simmental.

${ }^{2} 6.1$ or $6.5 \mathrm{MJ}$ of $\mathrm{NE}_{\mathrm{L}}$, with 150 or $250 \mathrm{~g} / \mathrm{kg}$ of $\mathrm{ECM}$, respectively.

${ }^{3} \mathrm{PMR}=$ partly mixed, farm-specific rations.

${ }^{4}$ Farm-specific high-yielding cow ration; target value for concentrates: $250 \mathrm{~g} / \mathrm{kg}$ of ECM.

period as well. Since the cows of some of the research farms were housed separately during the first DIM, no FI data were available for this period. Additionally, data were excluded if a sample day had less than 22 $\mathrm{h}$ records after checking the feed weighing technique. Furthermore, if the research farm fed PMR, total FI was only calculated if mixture and concentrates were available. Calendar days with extreme mean herd weights were also excluded by visual inspection. To use the records of the amount of milk, at least 2 milkings had to be available. One research farm worked with an automatic milking system with 24 -h data recording. Thus, lactation for further analysis was defined from 1 to 350 DIM. Observations outside the range of \pm 4 standard deviations of the mean value were excluded from further analyses. The structure of the data set before raw data editing is summarized in Table 2. Four farms [Futterkamp, Iden, Riswick (B), and Achselschwang] carried out more consecutive feeding experiments (e.g., 2-2-2 stands for 3 feeding experiments each with 2 groups). Additionally, Achselschwang included the Brown-Swiss breed in their data set. Furthermore, 2 experimental farms (Braunschweig and Dummerstorf) had no animals included in lactation 1 . The number of animals was subsumed into both breeds HF and SI: 557 HF and 125 SI for lactation 1, 509 for HF and 141 SI for lactation 2, $370 \mathrm{HF}$ and $135 \mathrm{SI}$ for lactation 3, and $512 \mathrm{HF}$ and 209 SI for lactation $\geq 4$.

The data were edited to ensure that the cows had at least one record per week: the resulting means for FI, $\mathrm{MY}$, and $\mathrm{EB}$ were $21.8 \mathrm{~kg}, 35.5 \mathrm{~kg}$, and $3.20 \mathrm{MJ}$ of $\mathrm{NE}_{\mathrm{L}}$ for $\mathrm{HF}$, and $20.2 \mathrm{~kg}, 27.4 \mathrm{~kg}$, and $1.06 \mathrm{MJ}$ of $\mathrm{NE}_{\mathrm{L}}$ for SI, respectively (Table 3). A comparison of the mean values of both breeds showed higher values for $\mathrm{HF}$ in both traits with $+2 \mathrm{~kg}$ of $\mathrm{FI}$ and $7.01 \mathrm{MJ}$ of $\mathrm{NE}_{\mathrm{L}}$, respectively (Table 4 ).

The EB was calculated as the difference between energy intake (MJ of $\mathrm{NE}_{\mathrm{L}} / \mathrm{d}$ ) and estimated energy requirements for maintenance, MY, growth (only for primiparous cows), and gestation. These terms were calculated by the following formulas predetermined by the project optiKuh according to the German Society of Nutrition Physiology. Energy intake was computed by summing energy amounts of eaten PMR and concentrates or TMR, respectively. Energy requirement for maintenance was calculated according to Kirchgeßner (2014):

maintenance costs $\left(\mathrm{MJ}\right.$ of $\left.\mathrm{NE}_{\mathrm{L}} / \mathrm{d}\right)=0.293 \times \mathrm{BW}^{0.75}$.

On some research farms, the cows were weighed weekly. In other research herds, the cows were automatically 
Table 2. Description of data set before editing: number of cows, breeds, feeding groups, lactations, and DIM depending on farm

\begin{tabular}{|c|c|c|c|c|c|c|}
\hline \multirow[b]{2}{*}{ Research farm } & \multirow{2}{*}{$\begin{array}{l}\text { No. of } \\
\text { cows }\end{array}$} & \multirow[b]{2}{*}{ Breed $^{1}$} & \multirow{2}{*}{$\begin{array}{l}\text { No. of feeding } \\
\text { groups }\end{array}$} & \multirow[b]{2}{*}{ Lactation $^{2}$} & \multicolumn{2}{|c|}{ DIM } \\
\hline & & & & & Mean & Range \\
\hline Braunschweig & 64 & $\mathrm{HF}$ & 4 & $2-5,9$ & 67 & $0-171$ \\
\hline Dummerstorf & 30 & $\mathrm{HF}$ & 2 & $2-3$ & 191 & $0-622$ \\
\hline Futterkamp & 179 & $\mathrm{HF}$ & $2-2-2^{3}$ & $1-8$ & 174 & $26-377$ \\
\hline Hohenheim & 51 & $\mathrm{HF}$ & 1 & $1-5,7-8$ & 59 & $0-464$ \\
\hline Iden & 188 & $\mathrm{HF}$ & $1-2^{3}$ & $1-10$ & 63 & $1-309$ \\
\hline Karkendamm & 341 & $\mathrm{HF}$ & 1 & $1-9$ & 173 & $11-627$ \\
\hline Neumühle & 199 & $\mathrm{HF}$ & 1 & $1-11$ & 95 & $1-405$ \\
\hline Riswick (A) & 83 & $\mathrm{HF}$ & 4 & $1-7$ & 165 & $0-405$ \\
\hline Riswick (B) & 239 & $\mathrm{HF}$ & $2-3-4^{3}$ & $1-10$ & 86 & $0-468$ \\
\hline Achselschwang & 105 & $\mathrm{SI}(\mathrm{BS})$ & $2-4-2^{3}$ & $1-6,9$ & 175 & $20-348$ \\
\hline Aulendorf & 59 & SI & 2 & $1-9$ & 159 & $0-431$ \\
\hline Grub & 97 & SI & 4 & $1-8,10$ & 160 & $0-462$ \\
\hline Triesdorf & 66 & SI & 2 & $1-7$ & 155 & $0-403$ \\
\hline
\end{tabular}

${ }^{1} \mathrm{HF}=$ Holstein-Friesian; SI $=$ Simmental; BS = Brown-Swiss.

${ }^{2}$ Range of lactation stages.

${ }^{3}$ Multiple numbers in no. of feeding groups = additional feeding experiments within feeding group.

weighed after every milking. Daily values were derived by averaging morning and evening BW. The energy requirement for MY was computed by multiplying ECM by $3.28\left(\mathrm{MJ}\right.$ of $\left.\mathrm{NE}_{\mathrm{L}} / \mathrm{kg}\right)$.

The energy requirements for growth of primiparous cows $\left(\mathrm{MJ}\right.$ of $\left.\mathrm{NE}_{\mathrm{L}} / \mathrm{d}\right)=0.007895 \mathrm{MJ}$ of $\mathrm{NE}_{\mathrm{L}} / \mathrm{kg} \times$ $\mathrm{BW}_{14}$, where $\mathrm{BW}_{14}$ represents the mean weight of the first 14 DIM.

The energy requirement during gestation (MJ of $\left.\mathrm{NE}_{\mathrm{L}} / \mathrm{d}\right)=\left(0.044 \times \mathrm{e}^{0.0162 \times \mathrm{t}}+\right.$ udder deposition $) / 0.29$, where $t$ represents the number of days after conception, and constants of udder deposition are $0.8 \mathrm{MJ}$ of $\mathrm{NE}_{\mathrm{L}} / \mathrm{d}$ (8th to 7 th week ante partum), 1.1 $\mathrm{MJ}$ of $\mathrm{NE}_{\mathrm{L}} / \mathrm{d}$ (6th to 4 th week ante partum), and $1.5 \mathrm{MJ}$ of $\mathrm{NE}_{\mathrm{L}} / \mathrm{d}$ (3rd week ante partum to expected calving date).
By comparing well-established parametric functions (1) the best fitting function for the average lactation curve was evaluated and chosen as the basis for (2) the evaluation of the best (co)variance function to model cow-specific lactation curves. Afterward, using the best fitting models lactation curves were calculated, and both repeatabilities and correlations between cow effects of different lactation stages were estimated.

To find the best function for fitting the fixed lactation curve within breed for the traits FI and EB, the 4 parametric functions Ali and Schaeffer (AS; Ali and Schaeffer, 1987) and the Legendre polynomials (LG; Brotherstone et al., 2000) of 2nd to 4th degree were compared regarding their goodness of fit within lactation ( 1 to $4 ; 1$ to 6 ); see Tables 6 and 7 . For the

Table 3. Description of data set after editing: mean and SD of feed intake, energy balance, milk yield, ECM, and energy intake (1 to 350 DIM)

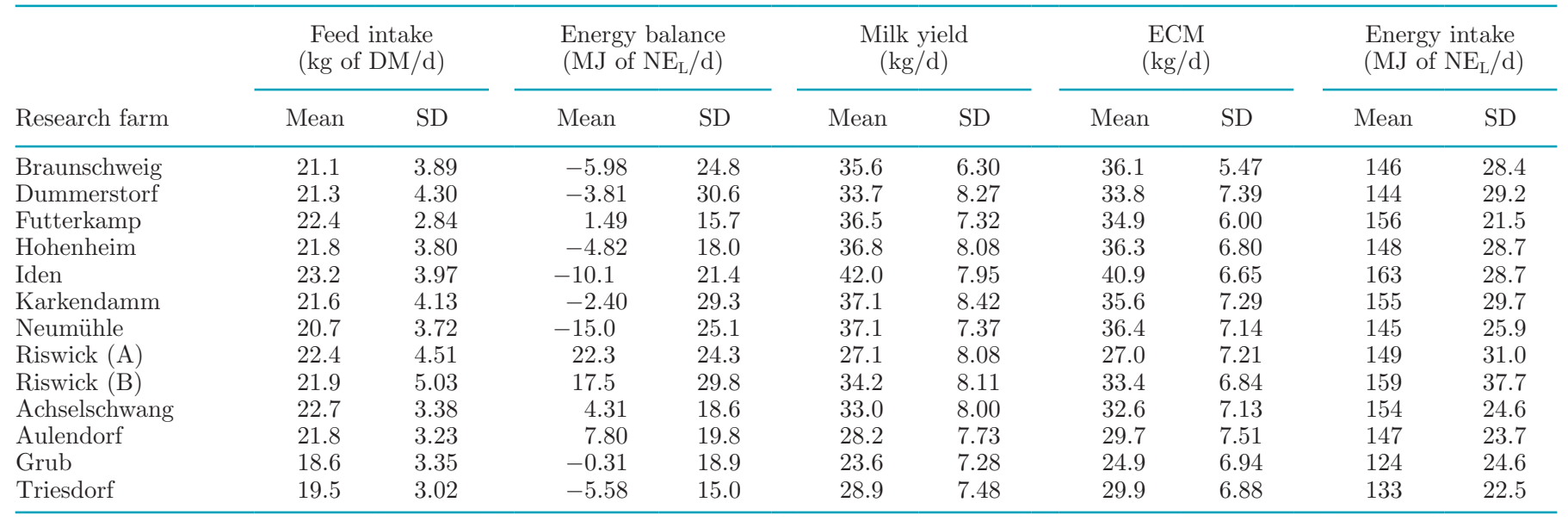


Table 4. Descriptive statistics for weekly averages of feed intake, milk yield, and energy balance as well as energy relevant traits for both breeds

\begin{tabular}{|c|c|c|c|c|c|}
\hline Trait & $\begin{array}{l}\text { No. of } \\
\text { cows }\end{array}$ & $\begin{array}{l}\text { No. of } \\
\text { lactations }\end{array}$ & Obs. $^{1}$ & Mean & $\mathrm{SD}$ \\
\hline \multicolumn{6}{|l|}{ Holstein-Friesian } \\
\hline Feed intake $(\mathrm{kg}$ of $\mathrm{DM} / \mathrm{d})$ & 1,341 & 1,928 & 40,012 & 21.8 & 4.25 \\
\hline Milk yield $(\mathrm{kg} / \mathrm{d})$ & 1,338 & 1,917 & 39,838 & 35.5 & 8.81 \\
\hline Energy balance $\left(\mathrm{MJ}\right.$ of $\left.\mathrm{NE}_{\mathrm{L}}\right)$ & 1,322 & 1,865 & 33,376 & 3.20 & 29.4 \\
\hline Feed intake $^{2}(\mathrm{~kg}$ of $\mathrm{DM} / \mathrm{d})$ & & & & 22.3 & 4.04 \\
\hline Weight $^{2}(\mathrm{~kg})$ & & & & 658 & 73.9 \\
\hline $\mathrm{ECM}^{2}(\mathrm{~kg} / \mathrm{d})$ & & & & 34.3 & 7.71 \\
\hline Milk yield $^{2}(\mathrm{~kg} / \mathrm{d})$ & & & & 35.8 & 8.76 \\
\hline Fat $^{2}(\%)$ & & & & 3.77 & 0.63 \\
\hline Protein $^{2}(\%)$ & & & & 3.31 & 0.32 \\
\hline \multicolumn{6}{|l|}{ Simmental } \\
\hline Feed intake $(\mathrm{kg}$ of $\mathrm{DM} / \mathrm{d})$ & 327 & 604 & 16,996 & 20.2 & 3.60 \\
\hline Milk yield (kg/d) & 326 & 603 & 16,933 & 27.4 & 8.16 \\
\hline Energy balance $\left(\mathrm{MJ}\right.$ of $\mathrm{NE}_{\mathrm{L}}$ ) & 326 & 583 & 14,527 & 1.06 & 18.9 \\
\hline Feed intake $^{2}(\mathrm{~kg}$ of $\mathrm{DM} / \mathrm{d})$ & & & & 20.4 & 3.41 \\
\hline Weight $^{2}(\mathrm{~kg})$ & & & & 750 & 75.3 \\
\hline $\mathrm{ECM}^{2}(\mathrm{~kg} / \mathrm{d})$ & & & & 28.3 & 7.58 \\
\hline Milk yield $^{2}(\mathrm{~kg} / \mathrm{d})$ & & & & 27.5 & 8.04 \\
\hline Fat $^{2}(\%)$ & & & & 4.24 & 0.61 \\
\hline $\operatorname{Protein}^{2}(\%)$ & & & & 3.59 & 0.33 \\
\hline
\end{tabular}

${ }^{1}$ Obs. = number of weekly averages.

${ }^{2}$ Traits for calculating energy balance.

trait MY, no model evaluation was conducted because the AS function is well established as shown in many former analyses (Buttchereit et al., 2010; Stamer et al., 2011; Melzer et al., 2017).

For the evaluation of the fixed lactation curve the following model was used:

$$
y_{i j k}=\mu+H T W_{i}+L N O_{j}+\sum_{l=1}^{m} b_{l} \times x_{i j k l}(\mathrm{~d})+e_{i j k}
$$

where $y_{i j k}$ is the observation of FI or EB, $\mu$ is the overall mean, $H T W_{i}$ is the fixed effect of the $i$ th herd-test week $(i=1, \ldots, 847)$ for FI and $\mathrm{EB}, L N O_{j}$ is the other fixed effect of the $j$ th lactation class $(j=1, \ldots, 4), b_{l}$ is set as the fixed $j$ th regression coefficient of the $l$ th function term of lactation day, $x$ is set as the function of the lactation curve (Table 5), and $e_{i j k}$ stands for the random residual effect.
The effect of the feeding group was tested in preceding within the farm analyses by choosing AS to model the lactation curves. In the case of significant group differences, the herd test week was extended by feeding group. Herd test weeks had to consist of at least $3 \mathrm{ob}-$ servations, otherwise they were added to a neighboring test week. The fixed regression models were analyzed using the SAS procedure MIXED and the maximum likelihood method (SAS, 2012). The function with the best model fit was chosen as the fixed lactation curve for further analyses. As already shown by Buttchereit et al. (2010), the described 4 functions (see Table 5) were chosen to model animal-dependent covariances between repeated measurements of the same cow in a second step of model evaluation to design final random regression models for statistical analyses of FI, MY, and EB.

For the evaluation of the random deviations from the fixed lactation curve, the following model was used:

Table 5. Function terms of lactation day (d) for 4 models using the Ali and Schaeffer curve (AS) and Legendre polynomials of second (LG2), third (LG3), and fourth degree (LG4) to simulate the lactation curve for 1 to $350 \mathrm{DIM}^{1}$

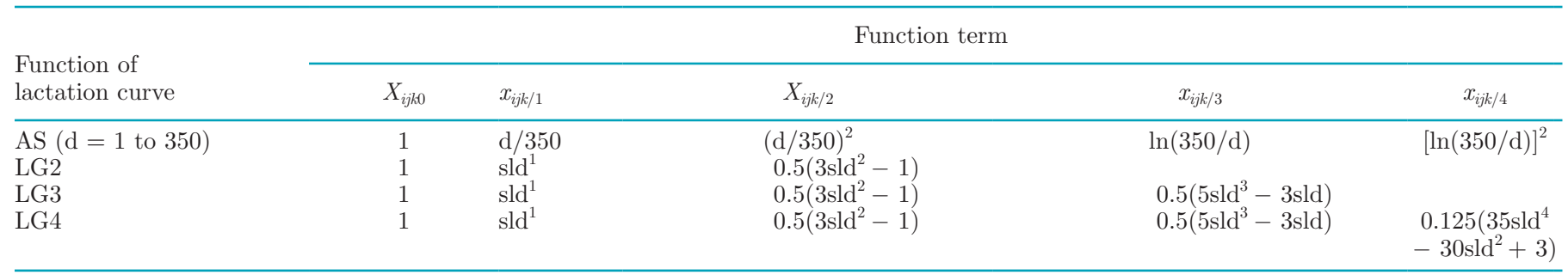

${ }^{1}$ sld $=$ standardized lactation day $\mathrm{d}$. 


$$
\begin{aligned}
& y_{i j k}=\mu+H T W_{i}+L N O_{j}+\sum_{n=1}^{m} b_{1} \times x_{i j k l}(\mathrm{~d}) \\
& +\sum_{n=1}^{m} \operatorname{cow}_{k m} \times x_{i j k l m}(\mathrm{~d})+e_{j k l},
\end{aligned}
$$

where $\operatorname{cow}_{k m}$ is the $m$ th random regression coefficient of the $k$ th animal. The random regression models were analyzed using the procedure MIXED in SAS (SAS, 2012) and the REML method. An unstructured covariance matrix was used for the random cow effect.

The corrected Akaike information criterion (AICC; Burnham and Anderson, 1998) and the Bayesian information criterion (BIC; Schwarz, 1978) were used as evaluation criteria of goodness of fit of the differently analyzed models.

$$
\begin{gathered}
\mathrm{AICC}=-2 \ln \mathrm{L}+2 \mathrm{~s}\left[\mathrm{~N}^{*} /\left(\mathrm{N}^{*}-\mathrm{s}-1\right)\right], \text { and } \\
\mathrm{BIC}=-2 \ln \mathrm{L}+\mathrm{s}\left(\ln \mathrm{N}^{*}\right) .
\end{gathered}
$$

In the case of the function of the curves for the general, fixed lactation curve (maximum likelihood estimation), $\mathrm{s}$ is set as the sum of fixed (p) and random effects (q), $\operatorname{lnL}$ is the logarithm of the restricted maximum likelihood function, $\mathrm{N}^{*}$ is the number of observations (n). For the computation of the goodness of fit for the function curve of the random cow effect (REML estimation), it is set as

$$
\begin{gathered}
\mathrm{s}=\mathrm{q} \text { and } \mathrm{N}^{*}=\mathrm{n}-\mathrm{p}(=\text { number of residual } \\
\text { degrees of freedom }) .
\end{gathered}
$$

Generally, the model that minimizes AICC or BIC should be applied, but if the values for AICC and BIC are similar, the simpler model should be preferred (Littell, 2007). The calculated correlation between the real observation and the predicted value was used as an additional criterion (Guo and Swalve, 1995). Furthermore, the estimated error variance was considered.

Based on the final random regression model, repeatabilities for all DIM (1 to 350) were calculated within breed by using the estimated regression coefficients. Also, cow-effect correlations, within trait, were computed between 12 DIM points, separated by regular intervals of $30 \mathrm{~d}$.

\section{RESULTS}

The evaluation criteria for the traits FI and EB of the fixed and random regression models are shown in Tables 6,7 , and 8 , and illustrate the goodness of fit of different lactation curve functions, represented as the difference to the best fitting model. Tables 6 and 7 refer to the fixed regression model. The criteria were computed within breed and trait. Additionally, a possible effect of the classification into 4 or 6 lactation classes on evaluation criteria was tested by comparing results

\begin{tabular}{|c|c|c|c|c|c|c|}
\hline \multirow[b]{3}{*}{ Breed } & \multirow[b]{3}{*}{ Lactation } & \multirow[b]{3}{*}{ Function } & \multicolumn{4}{|c|}{ Feed intake } \\
\hline & & & \multicolumn{2}{|c|}{ Function } & \multicolumn{2}{|c|}{ Function within lactation } \\
\hline & & & $\triangle \mathrm{AICC}$ & $\Delta \mathrm{BIC}$ & $\Delta \mathrm{AICC}$ & $\Delta \mathrm{BIC}$ \\
\hline \multirow[t]{8}{*}{$\overline{\mathrm{HF}}$} & \multirow[t]{4}{*}{1 to 4} & $\mathrm{AS}$ & 1,739 & 1,552 & 257 & 173 \\
\hline & & LG2 & 5.529 & 5,352 & 4.364 & 4.211 \\
\hline & & LG3 & 3,332 & 3,137 & 1,897 & 1,778 \\
\hline & & LG4 & 2,183 & 1,996 & 721 & 636 \\
\hline & \multirow[t]{4}{*}{1 to 6} & AS & 1,547 & 1,377 & $0^{\mathrm{A}}$ & $0^{\mathrm{B}}$ \\
\hline & & LG2 & 5,353 & 5,166 & 4,113 & 4,011 \\
\hline & & LG3 & 3.139 & 2.961 & 1.646 & 1.595 \\
\hline & & LG4 & 1,993 & 1,823 & 438 & 438 \\
\hline \multirow[t]{8}{*}{ SI } & \multirow[t]{4}{*}{1 to 4} & AS & $\begin{array}{r}1,30 \\
366\end{array}$ & $\begin{array}{r}1,020 \\
213\end{array}$ & 64 & $0^{\mathrm{C}}$ \\
\hline & & LG2 & 5,580 & 5,411 & 5,362 & 5,238 \\
\hline & & LG3 & 2,391 & 2,229 & 2,108 & 2,014 \\
\hline & & LG4 & 828 & 674 & 543 & 479 \\
\hline & \multirow{4}{*}{1 to 6} & $\mathrm{AS}$ & 300 & 161 & $0^{\mathrm{D}}$ & 11 \\
\hline & & LG2 & 5.517 & 5.363 & 5.301 & 5.222 \\
\hline & & LG3 & 2,333 & 2,187 & 2,053 & 2,019 \\
\hline & & LG4 & 763 & 624 & 475 & 486 \\
\hline
\end{tabular}
of both goodness of fit criteria. The best suited models

Table 6. Differences between the Bayesian information criterion ( $\triangle \mathrm{BIC})$ and corrected Akaike's information criterion $(\triangle \mathrm{AICC})$, for feed intake dependent on the fixed regression DIM functions Ali and Schaeffer (AS) and the Legendre polynomials of second (LG2), third (LG3), and fourth degree (LG4) for the data sets of the breeds Holstein-Friesian (HF) and Simmental (SI) for 1 to 350 DIM

${ }^{1}$ Absolute value: ${ }^{\mathrm{A}} 209,259 ;{ }^{\mathrm{B}} 216,759 ;{ }^{\mathrm{C}} 81,974 ;{ }^{\mathrm{D}} 74,594$. 
Table 7. Differences between the Bayesian information criterion ( $\triangle \mathrm{BIC})$ and corrected Akaike's information criterion $(\triangle \mathrm{AICC})$, for energy balance dependent on the fixed regression DIM functions Ali and Schaeffer (AS) and the Legendre polynomials of second (LG2), third (LG3), and fourth degree (LG4) for the data sets of the breeds Holstein-Friesian (HF) and Simmental (SI) for 1 to 350 DIM

\begin{tabular}{|c|c|c|c|c|c|c|}
\hline \multirow[b]{3}{*}{ Breed } & \multirow[b]{3}{*}{ Lactation } & \multirow[b]{3}{*}{ Function } & \multicolumn{4}{|c|}{ Energy balance } \\
\hline & & & \multicolumn{2}{|c|}{ Function } & \multicolumn{2}{|c|}{ Function within lactation $^{1}$} \\
\hline & & & $\triangle \mathrm{AICC}$ & $\Delta \mathrm{BIC}$ & $\triangle \mathrm{AICC}$ & $\Delta \mathrm{BIC}$ \\
\hline \multirow[t]{8}{*}{$\mathrm{HF}$} & \multirow[t]{4}{*}{1 to 4} & $\mathrm{AS}$ & 252 & 133 & 18 & $0^{\mathrm{A}}$ \\
\hline & & LG2 & 1,877 & 1,743 & 1,639 & 1,554 \\
\hline & & LG3 & 620 & 494 & 393 & 341 \\
\hline & & LG4 & 276 & 158 & 44 & 25 \\
\hline & \multirow[t]{4}{*}{1 to 6} & AS & 251 & 149 & $0^{\mathrm{B}}$ & 65 \\
\hline & & LG2 & 1,879 & 1,761 & 1,629 & 1,594 \\
\hline & & LG3 & 620 & 510 & 385 & 400 \\
\hline & & LG4 & 275 & 174 & 18 & 82 \\
\hline \multirow[t]{8}{*}{ SI } & \multirow[t]{4}{*}{1 to 4} & $\mathrm{AS}$ & 483 & 388 & 7 & $0^{\mathrm{C}}$ \\
\hline & & LG2 & 2,230 & 2,120 & 1,839 & 1,773 \\
\hline & & LG3 & 1,015 & 912 & 582 & 545 \\
\hline & & LG4 & 503 & 408 & 35 & 28 \\
\hline & \multirow[t]{4}{*}{1 to 6} & AS & 486 & 405 & $0^{\mathrm{D}}$ & 66 \\
\hline & & LG2 & 2,232 & 2,136 & 1,829 & 1,807 \\
\hline & & LG3 & 1,018 & 930 & 576 & 597 \\
\hline & & LG4 & 506 & 425 & 19 & 84 \\
\hline
\end{tabular}

${ }^{1}$ Absolute value: ${ }^{\mathrm{A}} 307,132 ;{ }^{\mathrm{B}} 300,379 ;{ }^{\mathrm{C}} 123,696 ;{ }^{\mathrm{D}} 117,187$.

for the fixed lactation curve for both traits and breeds seem to be the AS function. Additionally, the nested function within lactation accomplished better results than the alternative with lactation class as the main effect. The simpler model with 4 classes was chosen for further analyses due to the lack of clear differences between the models with 4 or 6 lactation classes.

Table 8 refers to the random regression part of the model. For both HF and SI, the Legendre polynomial of fourth degree (LG4) model shows the lowest information criteria and also the lowest residual variances. Results were not consistent for the correlations between observed and predicted trait values. Nevertheless, for these data, the best suited statistical model seems to be the one that includes the fixed effects herd test week, lactation class (4 classes), and the AS function as fixed regression. The LG4 should be chosen as the random regression.

The resulting parameter estimates of this model were used for the calculation of the fixed regression curves within lactation class. The intercept estimate, lactation class effect, and fixed regression coefficients were used for this calculation. Additionally, herd test week was considered by its overall mean effect, and random effect was set to its mean (0).

Figure 1 shows the average standardized error of the complete model (AS for fix lactation curve and LG4 for random cow effect), which were plotted against 1

Table 8. Differences between the Bayesian information criterion $(\Delta \mathrm{BIC})$ and corrected Akaike's information criterion $(\Delta \mathrm{AICC})$, correlation between recorded and predicted value $(\mathrm{R} q, \hat{\mathrm{q}})$ and the residual variances (var e) for energy balance and feed intake dependent on the random regression DIM functions Ali and Schaeffer (AS) and the Legendre polynomials of second (LG2), third (LG3), and fourth degree (LG4) for both breeds ${ }^{1}$

\begin{tabular}{|c|c|c|c|c|c|c|c|c|c|}
\hline \multirow[b]{2}{*}{ Breed $^{2}$} & \multirow[b]{2}{*}{ Function } & \multicolumn{4}{|c|}{ Feed intake } & \multicolumn{4}{|c|}{ Energy balance } \\
\hline & & $\Delta \mathrm{AICC}$ & $\Delta \mathrm{BIC}$ & var e & $\mathrm{R} \mathrm{q}, \hat{\mathrm{q}}$ & $\triangle \mathrm{AICC}$ & $\Delta \mathrm{BIC}$ & var e & $\mathrm{R} \mathrm{q}, \hat{\mathrm{q}}$ \\
\hline \multirow{3}{*}{$\mathrm{HF}$} & LG2 & 1,642 & 1,596 & 4.69 & 0.87 & 818 & 771 & 217.3 & 0.88 \\
\hline & LG3 & 765 & 766 & 4.48 & 0.88 & 302 & 276 & 209.1 & 0.89 \\
\hline & LG4 & $0^{\mathrm{A}}$ & $0^{\mathrm{B}}$ & 4.28 & 0.89 & $0^{\mathrm{C}}$ & $0^{\mathrm{D}}$ & 203.1 & 0.89 \\
\hline \multirow{2}{*}{ SI } & $\mathrm{AS}$ & 524 & 505 & 1.62 & 0.94 & 382 & 364 & 77.2 & 0.90 \\
\hline & LG4 & $0^{\mathrm{E}}$ & $0^{\mathrm{F}}$ & 1.54 & 0.95 & $0^{\mathrm{G}}$ & $0^{\mathrm{H}}$ & 73.3 & 0.91 \\
\hline
\end{tabular}

${ }^{1}$ Absolute values: ${ }^{\mathrm{A}} 180,491 ;{ }^{\mathrm{B}} 180,574 ;{ }^{\mathrm{C}} 275,773 ;{ }^{\mathrm{D}} 275,856 ;{ }^{\mathrm{E}} 58,535 ;{ }^{\mathrm{F}} 58,596 ;{ }^{\mathrm{G}} 102,880 ;{ }^{\mathrm{H}} 102,940$.

${ }^{2} \mathrm{HF}=$ Holstein-Friesian; SI $=$ Simmental. 

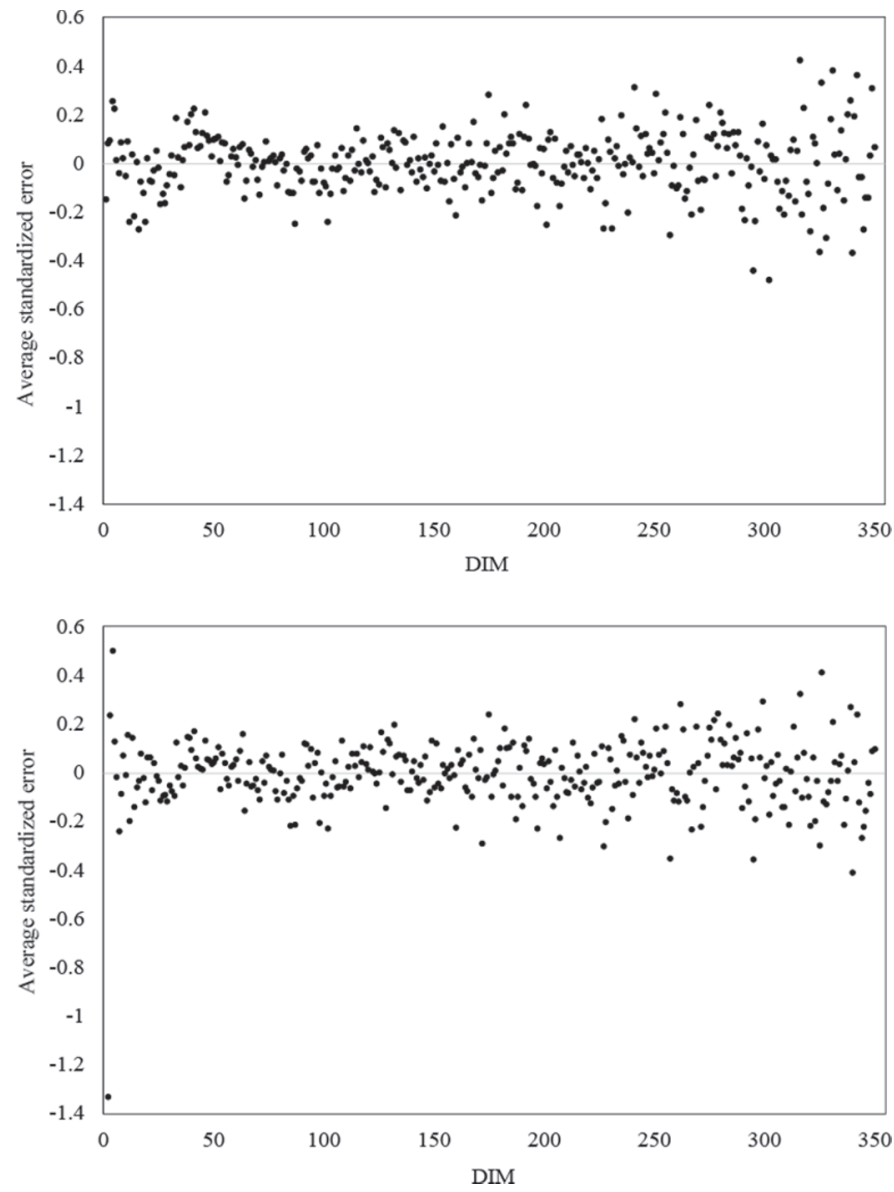

Figure 1. Distribution of average standardized error in course of lactation of feed intake (FI; top) and energy balance (EB; bottom) predicted by the final model [Ali and Schaeffer (AS) for the fixed lactation curve, Legendre polynomial of the fourth degree (LG4) for the random cow effect] from DIM 1 to 350 for Holstein-Friesian cows.

to 350 DIM. The almost homogeneous residual pattern underlined the chosen model. Figures for HF and both FI and EB traits are illustrated.

Figures 2 and 3 illustrate lactation curves for the first and second lactations FI and EB and MY. The energy deficit in the early lactation is indicated as a hatched area. Cows hit peak milk production before they hit peak FI. Generally, the difference between the first and second lactations is evidently higher in $\mathrm{HF}$ compared with SI lactation curves. The traits FI and MY are higher in second lactation, whereas the EB curve is lower in the second lactation in both breeds. Both breeds show similar trajectories of lactation in second lactation, but HF display a higher level overall. Cows show a more pronounced energy deficit (hatched area, Figure 2) in the initial stage of lactation in first lactation, but achieve a positive EB in second lactation around $10 \mathrm{~d}$ later than in first lactation with a switch at around DIM 50.
All in all, Figures 2 and 3 show the central and well-known problem of negative EB. The moment of highest MY (before 50 DIM) and highest FI (after 50 DIM) appear with a certain time, which results in an energy deficit. In consequence, body reserves were used for milk production, which in turn can cause metabolic stress and health problems. First lactating SI cows show a slightly negative EB after 200 DIM.

Repeatabilities for the traits FI, EB, and MY for both breeds in the course of lactation (DIM 1 to 350) are shown in Figure 4. The values ranged between 0.56 and 0.95 (HF) and 0.54 and 0.95 (SI). For both breeds, the highest repeatability was observed at the beginning and the end of lactation, whereas EB showed the poorest repeatability with values ranging between 0.49 to 0.85 . In comparison between the breeds, SI have a higher level of trajectories within traits. Table 9 (HF) and Table 10 (SI) provide correlations between cow effects at different lactations stages for FI (above the diagonal) and weekly EB (below the diagonal). Generally,
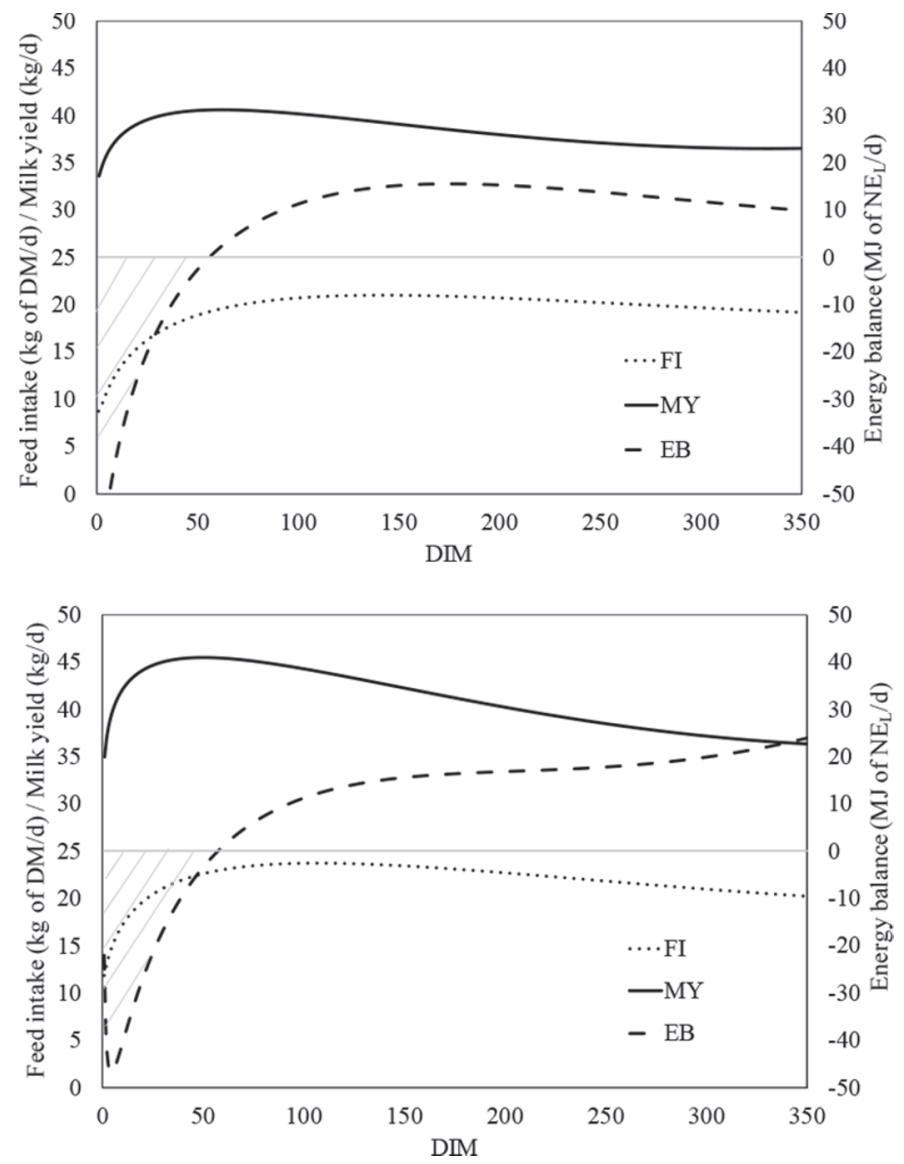

Figure 2. Lactation curves for feed intake (FI), milk yield (MY), and energy balance (EB) of Holstein-Friesian cows in first (top) and second (bottom) lactation modeled with the Ali and Schaeffer (AS) function. 

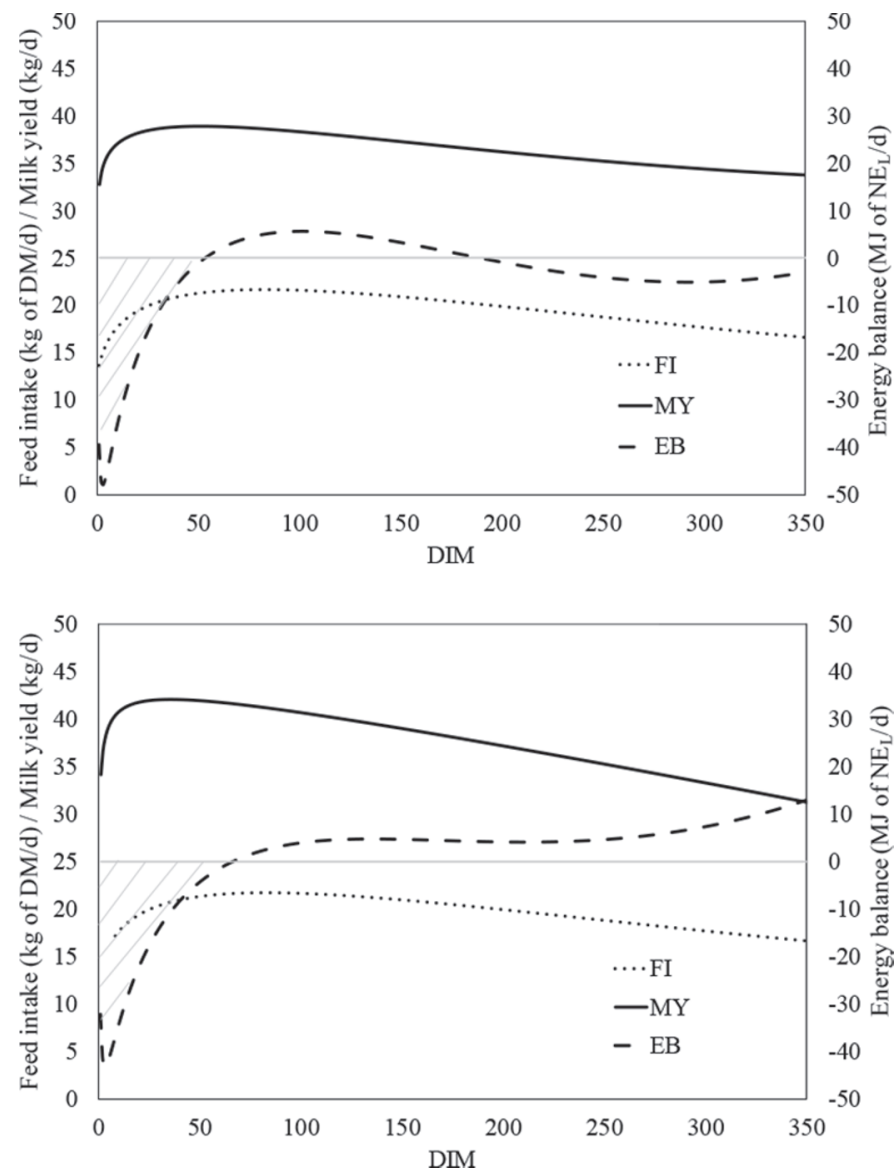

Figure 3. Lactation curves for feed intake (FI), milk yield (MY), and energy balance (EB) of Simmental cows in first (top) and second (bottom) lactation modeled with the Ali and Schaeffer (AS) function.

the FI correlations are higher than the EB correlations. Neighboring stages of lactation are more closely correlated than more distant stages. This accounts for HF, SI, and for both traits. Higher values were observed between adjacent DIM in the middle and at the end of lactation and lower estimates were observed between DIM records at the beginning of lactation. Correlations of FI at the beginning of lactation, the relevant period in this study, varied from 0.41 to 0.95 for $\mathrm{HF}$ and for SI 0.30 to 0.96 , respectively. The correlations for EB varied from 0.42 to 0.96 for $\mathrm{HF}$ and from 0.26 to 0.93 for SI.

\section{DISCUSSION}

The data set used for this study consists of lactation data for d 1 to 350 of lactation. To eliminate measurement errors, observations with deviating data from the range of \pm 4 standard deviations were excluded from analyses. Because the data were almost exclusively recorded in feeding experiments, pre-analyses were needed to check if the feeding groups were significant. In the case of significant feeding groups, the herd test week effect was extended to a herd test week group effect. Thus, one herd test week changed to 2 or 4 effect classes corresponding to the number of feeding groups. The results emphasize the necessity of pre-analyses of the significance of the feeding group effect. To investigate the goodness of fit for the different lactation models, it has to be considered that each model depends on the underlying data structure, such as duration of lactation and shape of lactation curve (Melzer et al., 2017). Lactation curves generally synthesize the main aspects of the shape of lactation and give good results when animal groups are homogeneous and fitted to average lactation patterns (Macciotta et al., 2015; Pulina et al., 2016). In this study these circumstances were given, and good results, which complied with literature, could be generated.

Fixed and random regression were used to estimate not only lactation curves but also repeatabilities and correlations between cow effects (Hüttmann et al., 2009). Random regression models permit the use of incomplete lactations and the subsequent inclusion of a large amount of data from the same animal (Bignardi et al., 2011). Pool et al. (2000) concluded that the trajectory of the curves are not well predicted by random regression models unless the complete data that are relevant to the trajectory were used.

The LG could be used to model the trajectories of random animal genetic and permanent environmental variations. In general, LG with minimal order should be used because the computation capacity of the application of a random regression model is limited. On the other hand, the LG with higher orders are useful when conventional orders fail due to better convergence (Pool et al., 2000), so LG4 was chosen in this study as the best alternative. Additionally, Pool et al. (2000) recommended the selection of LG4 for genetic and permanent environmental effect, because this model is well equipped. In general, random regression models performed better than fixed regression models. The fixed lactation curve for all cows was the same and differed only in height (Schaeffer and Jamrozik, 2008). The AS model for fixed regression was most suitable for both FI and EB, but the LG4 modeled the lactation curve almost as well as the AS model. Also, for other data sets and different studies, this model was observed to be the best suited (e.g., Buttchereit et al., 2010). The nested variants performed better for both traits because different courses of lactation justify the nesting.

The FI, EB, and MY lactation curves behave as expected: high energy deficits at the beginning of lactation are due to a delay in the increase in FI in combination with fast increasing MY. Differences be- 
Table 9. Correlations between cow effects of different DIM for feed intake (above the diagonal) and energy balance (below the diagonal) in Holstein-Friesian cows

\begin{tabular}{lllllllllllll}
\hline DIM & 10 & 40 & 70 & 100 & 130 & 160 & 190 & 220 & 250 & 280 & 310 & 340 \\
\hline 10 & & 0.76 & 0.53 & 0.41 & 0.33 & 0.29 & 0.26 & 0.22 & 0.17 & 0.13 & 0.1 & 0.06 \\
40 & 0.81 & & 0.93 & 0.80 & 0.65 & 0.52 & 0.47 & 0.46 & 0.45 & 0.45 & 0.42 & 0.16 \\
70 & 0.55 & 0.93 & & 0.95 & 0.82 & 0.97 & 0.62 & 0.57 & 0.54 & 0.53 & 0.52 & 0.28 \\
100 & 0.42 & 0.78 & 0.96 & & 0.96 & 0.86 & 0.77 & 0.67 & 0.59 & 0.54 & 0.54 & 0.39 \\
130 & 0.36 & 0.64 & 0.83 & 0.96 & & 0.97 & 0.89 & 0.77 & 0.64 & 0.56 & 0.55 & 0.45 \\
160 & 0.31 & 0.50 & 0.67 & 0.85 & 0.97 & & 0.97 & 0.87 & 0.73 & 0.63 & 0.60 & 0.46 \\
190 & 0.26 & 0.40 & 0.56 & 0.74 & 0.89 & 0.97 & & 0.96 & 0.86 & 0.77 & 0.70 & 0.41 \\
220 & 0.18 & 0.33 & 0.47 & 0.62 & 0.76 & 0.87 & 0.96 & & 0.97 & 0.90 & 0.81 & 0.36 \\
250 & 0.08 & 0.27 & 0.40 & 0.50 & 0.6 & 0.71 & 0.84 & 0.96 & & 0.98 & 0.88 & 0.33 \\
280 & -0.01 & 0.21 & 0.33 & 0.40 & 0.47 & 0.56 & 0.7 & 0.86 & 0.97 & & 0.94 & 0.40 \\
310 & -0.06 & 0.13 & 0.26 & 0.33 & 0.39 & 0.47 & 0.59 & 0.73 & 0.84 & 0.93 & 0.49 \\
340 & -0.00 & -0.01 & 0.08 & 0.21 & 0.31 & 0.37 & 0.39 & 0.39 & 0.40 & 0.50 & 0.77 & 0.67 \\
\hline
\end{tabular}

Table 10. Correlations between cow effects of different DIM for feed intake (above the diagonal) and energy balance (below the diagonal) in Simmental cows

\begin{tabular}{|c|c|c|c|c|c|c|c|c|c|c|c|c|}
\hline DIM & 10 & 40 & 70 & 100 & 130 & 160 & 190 & 220 & 250 & 280 & 310 & 340 \\
\hline 40 & 0.82 & & 0.90 & 0.78 & 0.68 & 0.61 & 0.58 & 0.56 & 0.55 & 0.53 & 0.49 & 0.36 \\
\hline 70 & 0.51 & 0.90 & & 0.96 & 0.87 & 0.77 & 0.68 & 0.61 & 0.55 & 0.50 & 0.46 & 0.34 \\
\hline 130 & 0.09 & 0.45 & 0.74 & 0.93 & & 0.97 & 0.90 & 0.79 & 0.65 & 0.54 & 0.50 & 0.46 \\
\hline 160 & -0.00 & 0.23 & 0.51 & 0.77 & 0.94 & & 0.97 & 0.88 & 0.74 & 0.62 & 0.57 & 0.52 \\
\hline 190 & -0.06 & 0.08 & 0.31 & 0.57 & 0.80 & 0.94 & & 0.96 & 0.86 & 0.75 & 0.67 & 0.56 \\
\hline 280 & -0.20 & -0.10 & -0.02 & 0.05 & 0.15 & 0.31 & 0.53 & 0.78 & 0.95 & & 0.95 & 0.68 \\
\hline 310 & -0.29 & -0.20 & -0.09 & -0.01 & 0.08 & 0.21 & 0.38 & 0.6 & 0.78 & 0.92 & & 0.86 \\
\hline 340 & -0.34 & -0.32 & -0.18 & -0.03 & 0.11 & 0.20 & 0.26 & 0.31 & 0.23 & 0.35 & 0.80 & \\
\hline
\end{tabular}

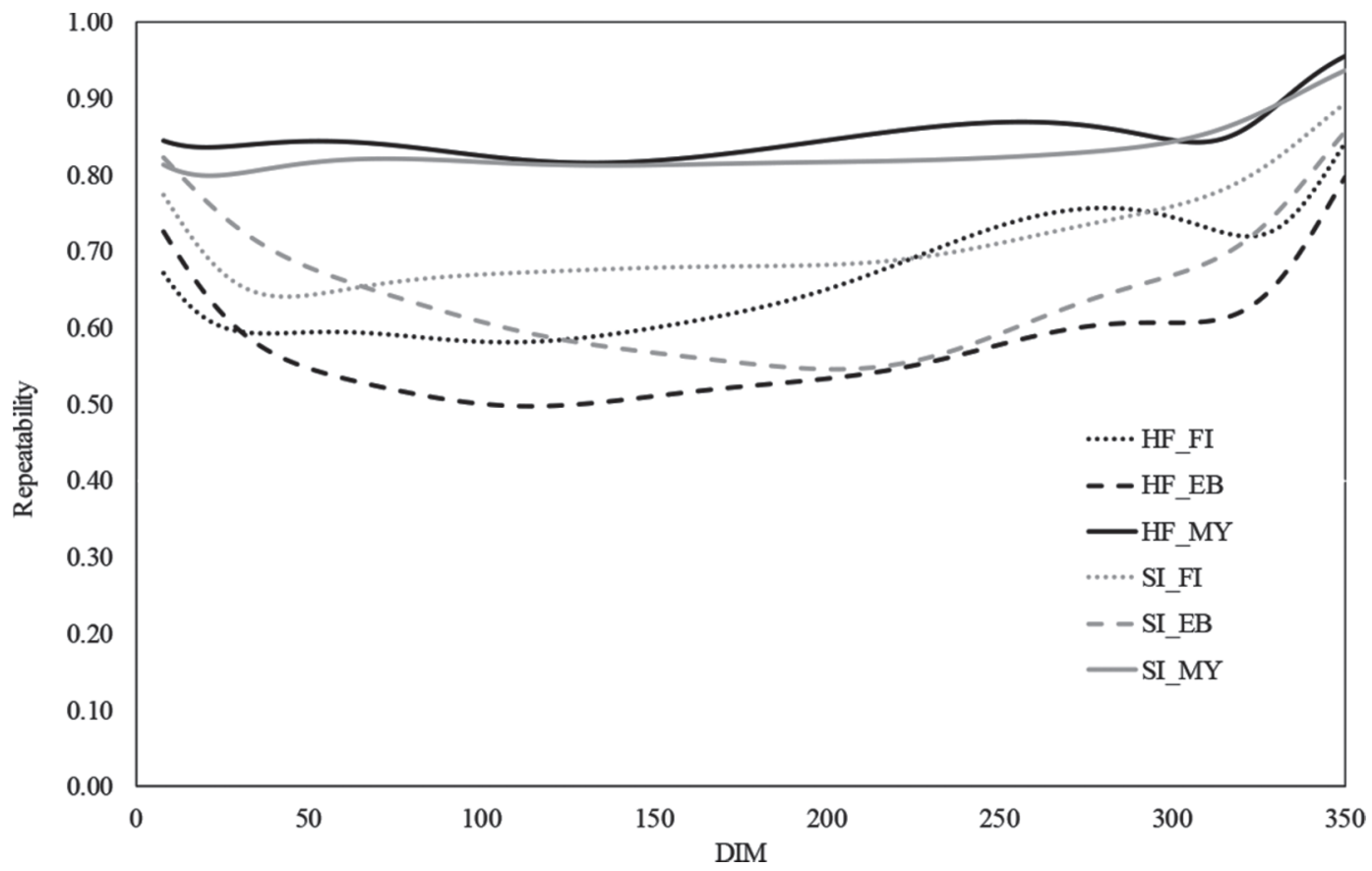

Figure 4. Repeatability of feed intake (FI), energy balance (EB), and milk yield (MY) for Holstein-Friesian (HF; black) and Simmental (SI; gray) cows. 
tween first lactating HF and SI cows can arise from different growth rates. For the calculation of EB, $15 \%$ higher energy requirements for growth of primiparous cows are assumed. It seems the assumption of $15 \%$ is too high for SI. So, breed-specific growth requirements might be necessary in the future. The trajectories of the mean lactation curves are similar to the results in literature (Hüttmann et al., 2009; Macciotta et al., 2015; Li et al., 2018). Clear differences during the course of lactation between the traits can be observed. At first sight, the EB estimates show slightly different patterns compared with the FI cause of measurements that are more reliable. The trajectory of the curves of lactation of the current study were similar to the trajectory of least squares means phenotypic values by day of lactation reported by Coffey et al. (2001). Lactation curves for MY tend to have a peak around 40 DIM, which is conforms to the studies of Hüttmann et al. (2009) and López et al. (2015). Also, the results for FI are in accordance with Hüttmann et al. (2009). The EB curves for optiKuh cows represented in this data set are consistent with those reported in other studies (de Vries and Veerkamp, 2000; Coffey et al., 2001). Hüttmann et al. (2009) assumed that EB depends more on MY than FI and Buttchereit et al. (2012) also assigned meanings to FI in this relation. Additionally, Villa-Godoy et al. (1988) and Veerkamp et al. (2000) suggested that the nutrient intake is a big factor influencing the metabolic situation. To analyze the relationships between these traits within the course of lactation, the run of the curves points to a causal relationship between the 3 traits. However, it must be considered that FI and MY are measured directly, whereas EB lactation curves are modeled by several traits such as MY, milk ingredients, FI, and BW.

Possibilities in calculating FI with auxiliary characteristics, as Egger-Danner et al. (2015) showed, involves risks of inaccuracy and a higher rate of error. Buttchereit et al. (2012) described the possibility to build the energy status with fat:protein ratio. Furthermore, the difference between the first and second lactations within the breed show an enhanced FI intake, higher MY, and improved EB. Intriguingly, the EB curve reaches the positive area in the same time (around $40-80 \mathrm{~d}$ postpartum) in both lactations, but has a generally higher trajectory in second lactation. These findings are in line with the analyses of Villa-Godoy et al. (1988), de Vries and Veerkamp (2000), and Coffey et al. (2002). The FI and EB stabilize around the same time. The lactation curves of SI population are lower with a better persistency compared with the trajectory of HF population, caused by the fact of a lower energy deficit and less compensatory scoring (Coffey et al., 2001).
High repeatability estimates suggest a precise and ideal measurement over the period (Buttchereit et al., 2012). Furthermore, high repeatabilities promise high heritability. Thereby, highly useful genetic variation for breeding editing is possible under the assumption that the proportion of the permanent environment is not dominated in the genetic model, which is split into permanent environmental effect and an additive genetic effect of the cow.

Not surprisingly, high repeatabilities were found for FI (0.59 to 0.84 for $\mathrm{HF}$ and 0.64 to 0.89 for SI), which confirms the results of the study by Tetens et al. (2014), who found very high values for DIM up to 0.56 . In contrast, the studies of Veerkamp and Thompson (1999), Coffey et al. (2002), and Berry et al. (2007) reported high residual variance for FI in early lactation. Explanations for different levels of repeatabilities between SI and HF are inter alia different technique measurement (e.g., access to feed of SI-farms is controlled by troughs). This means a more precise time allocation for visits of the individual cow can be possible. One HF research farm has free access and thus faster changes between cows. For milk, there is a broad consistency of the measurements between SI and HF research farms.

The low correlations between cow effects for EB between early and late DIM are supported by the results of Buttchereit et al. (2010) who observed even a negative phenotypic correlation. The correlations between cow effects, referring to the HF data set, are higher at the beginning of the lactation based on EB, which is in line with the results of Reist et al. (2002) and Buttchereit et al. (2010). The development of both traits is the same in the SI population with slightly lower values. The EB values decreased from early and late DIM. Under the assumption of correlations between cow effects generated in this study, selection for higher FI at the beginning does not necessarily lead to over-conditioning at the end of lactation.

\section{CONCLUSIONS}

This study evaluated FI and EB during lactation and the estimation of the parameters for the random regression model for each trait. The results of the lactation curves, repeatability, and animal correlations between DIM are consistent with those found in the literature. The animal correlations between different DIM ranged between 0.74 and 0.96 for FI and 0.81 and 0.96 for EB, during the beginning of lactation. The data set of the optiKuh project provides good possibilities to use the traits FI or EB for selective decisions and the foundation for an estimation of genetic parameters and variance components such as heritabilities to generate reliable 
and genomic estimated breeding values for FI and EB in German HF and SI populations. The estimated correlations between cow effects of different stages suggest possibilities to select for higher FI at the beginning of lactation to avoid high energy deficits associated with only small changes in FI at the end of lactation. The optiKuh data represent an essential basis for a national reference population. These data provide possibilities for a national or even an international expansion to obtain reliable breeding values for FI or EB.

\section{ACKNOWLEDGMENTS}

The project was supported by funds from the Federal Ministry of Food and Agriculture (BMEL) based on a decision of the Parliament of the Federal Republic of Germany via the Federal Office for Agriculture and Food (BLE) under the innovation support program (Germany).

\section{REFERENCES}

Ali, T., and L. R. Schaeffer. 1987. Accounting for covariance among test day milk yields in dairy cows. Can. J. Anim. Sci. 67:637-644. https://doi.org/10.4141/cjas87-067.

Banos, G., M. P. Coffey, R. F. Veerkamp, D. P. Berry, and E. Wall. 2012. Merging and characterising phenotypic data on conventional and rare traits from dairy cattle experimental resources in three countries. Animal 6:1040-1048. https://doi.org/10.1017/ S1751731111002655.

Berry, D. P., M. P. Coffey, J. E. Pryce, Y. de Haas, P. Løvendahl, N. Krattenmacher, J. J. Crowley, Z. Wang, D. Spurlock, K. Weigel, K. Macdonald, and R. F. Veerkamp. 2014. International genetic evaluations for feed intake in dairy cattle through the collation of data from multiple sources. J. Dairy Sci. 97:3894-3905. https://doi .org/10.3168/jds.2013-7548.

Berry, D. P., B. Horan, M. O'Donovan, F. Buckley, E. Kennedy, M. McEvoy, and P. Dillon. 2007. Genetics of grass dry matter intake, energy balance, and digestibility in grazing Irish dairy cows. J. Dairy Sci. 90:4835-4845. https://doi.org/10.3168/jds.2007-0116.

Bignardi, A. B., L. El Faro, R. A. A. Torres Júnior, V. L. Cardoso, P. F. Machado, and L. G. Albuquerque. 2011. Random regression models using different functions to model test-day milk yield of Brazilian Holstein cows. Genet. Mol. Res. 10:3565-3575. https:// doi.org/10.4238/2011.October.31.4.

Boichard, D., and M. Brochard. 2012. New phenotypes for new breeding goals in dairy cattle. Animal 6:544-550. https://doi.org/10 $.1017 /$ S1751731112000018.

Brotherstone, S., I. M. S. White, and K. Meyer. 2000. Genetic modelling of daily milk yield using orthogonal polynomials and parametric curves. Anim. Sci. 70:407-415. https://doi.org/10.1017/ S1357729800051754.

Burnham, K. P., and D. R. Anderson. 1998. Model Selection and Inference: A Practical Information-Theoretic Approach. Springer, New York, NY.

Butler, W. R. 2003. Energy balance relationships with follicular development, ovulation and fertility in postpartum dairy cows. Livest. Prod. Sci. 83:211-218. https://doi.org/10.1016/S0301 $-6226(03) 00112-\mathrm{X}$

Buttchereit, N., E. Stamer, W. Junge, and G. Thaller. 2010. Evaluation of five lactation curve models fitted for fat:protein ratio of milk and daily energy balance. J. Dairy Sci. 93:1702-1712. https:/ /doi.org/10.3168/jds.2009-2198.
Buttchereit, N., E. Stamer, W. Junge, and G. Thaller. 2012. Modellevaluierung und Schätzung genetischer Parameter für Energiebilanz und verwandte Merkmale bei Milchkühen. Zuchtungskunde 84:74-89.

Coffey, M. P., G. C. Emmans, and S. Brotherstone. 2001. Genetic evaluation of dairy bulls for energy balance traits using random regression. Anim. Sci. 73:29-40. https://doi.org/10.1017/ S1357729800058021.

Coffey, M. P., G. Simm, and S. Brotherstone. 2002. Energy balance profiles for the first three lactations of dairy cows estimated using random regression. J. Dairy Sci. 85:2669-2678. https://doi.org/10 .3168/jds.S0022-0302(02)74352-X.

Coffey, M. P., G. Simm, J. D. Oldham, W. G. Hill, and S. Brotherstone. 2004. Genotype and diet effects on energy balance in the first three lactations of dairy cows. J. Dairy Sci. 87:4318-4326. https://doi.org/10.3168/jds.S0022-0302(04)73577-8.

Collard, B. L., P. J. Boettcher, J. C. M. Dekkers, D. Petitclerc, and L. R. Schaeffer. 2000. Relationships between energy balance and health traits of dairy cattle in early lactation. J. Dairy Sci. 83:2683-2690. https://doi.org/10.3168/jds.S0022-0302(00)75162 $-9$.

Connor, E. E. 2015. Invited review: Improving feed efficiency in dairy production: Challenges and possibilities. Animal 9:395-408. https: //doi.org/10.1017/S1751731114002997.

de Haas, Y., M. P. L. Calus, R. F. Veerkamp, E. Wall, M. P. Coffey, H. D. Daetwyler, B. J. Hayes, and J. E. Pryce. 2012. Improved accuracy of genomic prediction for dry matter intake of dairy cattle from combined European and Australian data sets. J. Dairy Sci. 95:6103-6112. https://doi.org/10.3168/jds.2011-5280.

de Haas, Y., J. E. Pryce, M. P. L. Calus, E. Wall, D. P. Berry, P. Lovendahl, N. Krattenmacher, F. Miglior, K. Weigel, D. Spurlock, K. A. Macdonald, B. Hulsegge, and R. F. Veerkamp. 2015. Genomic prediction of dry matter intake in dairy cattle from an international data set consisting of research herds in Europe, North America, and Australasia. J. Dairy Sci. 98:6522-6534. https://doi .org/10.3168/jds.2014-9257.

de Vries, M. J., and R. F. Veerkamp. 2000. Energy balance of dairy cattle in relation to milk production variables and fertility. J. Dairy Sci. 83:62-69. https://doi.org/10.3168/jds.S0022-0302(00)74856-9.

Egger-Danner, C., J. B. Cole, J. E. Pryce, N. Gengler, B. Heringstad, A. Bradley, and K. F. Stock. 2015. Invited review: Overview of new traits and phenotyping strategies in dairy cattle with a focus on functional traits. Animal 9:191-207. https://doi.org/10.1017/ S1751731114002614.

Guo, Z., and H. H. Swalve. 1995. Modelling of the lactation curve as a sub-model in the evaluation of test day records. Pages 1-4 in Proc. Interbull Mtg. Prague, International Bull Evaluation Service, Uppsala, Sweden.

Hüttmann, H., E. Stamer, W. Junge, G. Thaller, and E. Kalm. 2009 Analysis of feed intake and energy balance of high-yielding first lactating Holstein cows with fixed and random regression models. Animal 3:181-188. https://doi.org/10.1017/S175173110800325X.

Ingvartsen, K. L., and J. B. Andersen. 2000. Integration of metabolism and intake regulation: A review focusing on periparturient animals. J. Dairy Sci. 83:1573-1597. https://doi.org/10.3168/jds .S0022-0302(00)75029-6.

Jamrozik, J., and L. R. Schaeffer. 1997. Estimates of genetic parameters for a test day model with random regressions for yield traits of first lactation Holsteins. J. Dairy Sci. 80:762-770. https://doi .org/10.3168/jds.S0022-0302(97)75996-4.

Jensen, J. 2001. Genetic evaluation of dairy cattle using test-day models. J. Dairy Sci. 84:2803-2812. https://doi.org/10.3168/jds.S0022 -0302(01)74736-4.

Kirchgeßner, M. 2014. Tierernährung. 14th ed. DLG-Verlag, Frankfurt am Main, Germany.

Li, B., W. F. Fikse, P. Løvendahl, J. Lassen, M. H. Lidauer, P. Mäntysaari, and B. Berglund. 2018. Genetic heterogeneity of feed intake, energy-corrected milk, and body weight across lactation in primiparous Holstein, Nordic Red, and Jersey cows. J. Dairy Sci. 101:10011-10021. https://doi.org/10.3168/jds.2018-14611. 
Littell, R. C. 2007. SAS for mixed models. 2nd ed. SAS Press, Cary, NC.

López, S., J. France, N. E. Odongo, R. A. McBride, E. Kebreab, O. AlZahal, B. W. McBride, and J. Dijkstra. 2015. On the analysis of Canadian Holstein dairy cow lactation curves using standard growth functions. J. Dairy Sci. 98:2701-2712. https://doi.org/10 $.3168 /$ jds.2014-8132.

Macciotta, N. P. P., G. Gaspa, L. Bomba, D. Vicario, C. Dimauro, M. Cellesi, and P. Ajmone-Marsan. 2015. Genome-wide association analysis in Italian Simmental cows for lactation curve traits using a low-density (7K) SNP panel. J. Dairy Sci. 98:8175-8185. https:/ /doi.org/10.3168/jds.2015-9500.

Melzer, N., S. Trißl, and G. Nürnberg. 2017. Short communication: Estimating lactation curves for highly inhomogeneous milk yield data of an F2population (Charolais $\times$ German Holstein). J. Dairy Sci. 100:9136-9142. https://doi.org/10.3168/jds.2017-12772.

Pool, M. H., L. L. G. Janss, and T. H. E. Meuwissen. 2000. Genetic parameters of Legendre polynomials for first parity lactation curves. J. Dairy Sci. 83:2640-2649. https://doi.org/10.3168/jds.S0022 $-0302(00) 75157-5$.

Pulina, G., N. Macciotta, and A. Nudda. 2016. Milk composition and feeding in the Italian dairy sheep. Ital. J. Anim. Sci. 4(sup1):5-14. https://doi.org/10.4081/ijas.2005.1s.5.

Reist, M., D. Erdin, D. von Euw, K. Tschuemperlin, H. Leuenberger, Y. Chilliard, H. M. Hammon, C. Morel, C. Philipona, Y. Zbinden, N. Kuenzi, and J. W. Blum. 2002. Estimation of energy balance at the individual and herd level using blood and milk traits in highyielding dairy cows. J. Dairy Sci. 85:3314-3327. https://doi.org/10 3168/jds.S0022-0302(02)74420-2.

SAS. 2012. SAS 9.2 TS Level 1 Mo., SAS Institute Inc., Cary, NC.

Schaeffer, L. R., and J. Jamrozik. 2008. Random regression models: A longitudinal perspective. J. Anim. Breed. Genet. 125:145-146. https://doi.org/10.1111/j.1439-0388.2008.00748.x.

Schwarz, G. 1978. Estimating the dimension of a model. Ann. Stat. 6:461-464. https://doi.org/10.1214/aos/1176344136.

Spurlock, D. M., J. C. M. Dekkers, R. Fernando, D. A. Koltes, and A Wolc. 2012. Genetic parameters for energy balance, feed efficiency, and related traits in Holstein cattle. J. Dairy Sci. 95:5393-5402. https://doi.org/10.3168/jds.2012-5407.

Stamer, E., W. Brade, and G. Thaller. 2011. Modellentwicklung und Schätzung genetischer Parameter für den Harnstoffgehalt in der Milch erst- und zweitlaktierender Holstein-Kühe. Zuchtungskunde 83:104-117.
Tetens, J., G. Thaller, and N. Krattenmacher. 2014. Genetic and genomic dissection of dry matter intake at different lactation stages in primiparous Holstein cows. J. Dairy Sci. 97:520-531. https://doi .org/10.3168/jds.2013-7301.

Uddin, M. E., T. Meuwissen, and R. F. Veerkamp. 2018. Adjusting for heterogeneity of experimental data in genetic evaluation of dry matter intake in dairy cattle. J. Anim. Breed. Genet 135:28-36. https://doi.org/10.1111/jbg.12300.

Veerkamp, R. F., J. K. Oldenbroek, H. J. van der Gaast, and J. H. J. van der Werf. 2000. Genetic correlation between days until start of luteal activity and milk yield, energy balance, and live weights. J. Dairy Sci. 83:577-583. https://doi.org/10.3168/jds.S0022 $-0302(00) 74917-4$.

Veerkamp, R. F., J. E. Pryce, D. Spurlock, D. P. Berry, M. P. Coffey P. Løvendahl, R. d. van Linde, J. Bryant, F. Miglior, Z. Wang, M. Winters, N. Krattenmacher, N. Charfeddine, J. Pedersen, and Y. de Haas. 2013. Selection on feed intake of feed efficiency: A position paper from gDMI breeding goal discussion. Interbull Bull. $47: 15-22$.

Veerkamp, R. F. and R. Thompson. 1999. Multi-trait covariance functions to estimate genetic correlations between milk yield, drymatter intake and live weight during lactation. Metabolic stress in dairy cows. J. D. Oldham, G. Simm, A. F. Groen, B. L. Nielsen, J. E. Pryce, and T. L. J. Lawrence, ed. Br. Soc. Anim. Sci., Occasional Publication No. 24:147-151.

Villa-Godoy, A., T. L. Hughes, R. S. Emery, L. T. Chapin, and R. L. Fogwell. 1988. Association between energy balance and luteal function in lactating dairy cows. J. Dairy Sci. 71:1063-1072. https:// doi.org/10.3168/jds.S0022-0302(88)79653-8.

von Leesen, R., J. Tetens, E. Stamer, W. Junge, G. Thaller, and N. Krattenmacher. 2014. Effect of genetic merit for energy balance on luteal activity and subsequent reproductive performance in primiparous Holstein-Friesian cows. J. Dairy Sci. 97:1128-1138. https://doi.org/10.3168/jds.2013-7185.

Yao, C., G. de Los Campos, M. J. Vandehaar, D. M. Spurlock, L. E. Armentano, M. Coffey, Y. de Haas, R. F. Veerkamp, C. R. Staples, E. E. Connor, Z. Wang, M. D. Hanigan, R. J. Tempelman, and K. A. Weigel. 2017. Use of genotype $\times$ environment interaction model to accommodate genetic heterogeneity for residual feed intake, dry matter intake, net energy in milk, and metabolic body weight in dairy cattle. J. Dairy Sci. 100:2007-2016. https://doi.org/10.3168/ jds.2016-11606. 